\title{
The effect of leadership styles on employees' innovative work behavior
}

\author{
Ahmad Fathi Alheet ${ }^{\mathrm{a}}$, Ahmad Al Adwan ${ }^{\mathrm{b}}$, Ahmad Yousef Areiqat ${ }^{\mathrm{c}}$, Ahmad. M.A. Zamil ${ }^{\mathrm{d}^{*}}$ and Mohamed \\ A. Saleh ${ }^{\mathrm{e}}$
}

a Associate professor, Department of Business Administration, Business School, Al-Ahliyya Amman University. Amman Jordan

${ }^{b}$ Associate Professor and Head of Marketing Department, Business School, Al-Ahliyya Amman University, Amman, Jordan

${ }^{c}$ Professor, Department of Business Administration, Business School, Al-Ahliyya Amman University. Amman, Jordan

${ }^{d}$ Associate Professor, Department of Marketing, College of Business Administration, Prince Sattam bin Abdulaziz University, Saudi Arabia ${ }^{e}$ Business School, Al-Ahliyya Amman University, Jordan

\section{H R O N I C L E}

Article history:

Received: June 27, 2020

Received in revised format:

August 102020

Accepted: August 10, 2020

Available online:

August 10, 2020

Keywords:

Leadership styles

Innovative work behavior

Al-Ahliyya Amman University

\section{A B S T R A C T}

This study aims to investigate the impact of leadership styles (transformational leadership style, transactional leadership style, and Laisser-Faire leadership style) on employees' innovative work at Al-Ahliyya Amman University Employees. It follows the descriptive analytical approach by distributing a questionnaire to a sample of 461 employees following the convenience sampling technique. The findings show a positive statistically significant impact of transformational leadership style on employees' innovative work behavior, while there was a negative statistically significant impact of transactional and Laisserfaire leadership styles on the employees' innovative work behavior at Al-Ahliyya Amman University Employees.

\section{Introduction}

As the birth of a new idea begins primarily in the minds of individuals (De Jong \& Den Hartog, 2010) the majority of companies emphasize that the main source of creativity is not related to any element other than company employees and their behavior (Dörner, 2012), so creative behavior is one of the best ways to enhance the creativity of the organization (Mytelka $\&$ Smith, 2002). Nowadays, due to the volatility, dynamism of business environment, and the aggressive competition, employees are driven to contend with innovation through getting engaged in innovative behavior (Hong, Liao, Raub \& Han, 2016). This engagement is inevitable to take place without the role of leadership. This is because that leaders motivate their sub-ordinates through the traits, they possess to transcend their individual goals and gains towards a more important vision: the prosperity of the organization and the increase of its creative outputs (Mintzberg, 2010). In the same vein, leaders exert great influence on employees' behavior towards their jobs, and with the changing role of leaders in today's organizations, the success of any organization depends on the leadership style exercised by the leader (Saleem, Tufail, Atta \& Asghar, 2015). Hence, it is crucial to identify which leadership style enhances/ promotes followers' innovative work behavior (Kark, Van Dijk \& Vashdi, 2018). This calls organizations to emphasize on such behavior, especially as the latter becomes one of the critical issues that might impede their survival. Additionally, with the fast changes brought by globalization, customers' access to unlimited amount of information has raised massively, adding more complexity to their demands and enormously increasing their needs that they seek to be fulfilled (González - roma, 2008; Sarros, Cooper \& Santora, 2008). Consequently, organizations were driven to find out all possible paths to nurture such behavior as perceived the only option to assure remaining in business. Thus, organizations were confronted/challenged/provoked with two options: either to adapt themselves to cope with these accelerating changes by promoting their employees' innovative work behavior, or to get out of the competition and * Corresponding author.

E-mail address: am.zamil@psau.edu.sa (A. M. A. Zamil) 
leave the market in which they operate (De Spiegelaere, Van Gyes, De Witte, Niesen \& Van Hootegem, 2014). Additionally, the problem associated with the lack of innovative behavior can become worthier as it will undermine the organizations' ability to implement their strategies, and thus, fail to achieve their goals (Shojaei \& Siuki, 2014). Drawing on the above, innovative work behavior has emerged as a challenging issue put in face of organizations, as today's employees are far more required to proactively deal with complex issues in their work context that are not expected nor prescribed in their job descriptions (Joo \& Bennett, 2018). The manifestation of this threat is due to the fact that along years, innovative initiatives have been recognized as the cornerstone for organizational growth and success (Zhou \& Hoever, 2014; Zhou \& Shalley, 2011) with sub-sequent critical outcomes (Anderson, Potocnik \& Zhou, 2014; Liu, Jiang, Shalley, Keem \& Zhou, 2016). This called organizations to develop effective leadership to drive followers from routine performance of duties towards challenging the status quo (Wang, Tsai \& Tsai, 2014). Despite that, there is a plethora of literature that has examined leadership styles and their relationships with employees' innovative behavior, but how leadership influences this behavior was not sufficiently investigated (Basu \& Green, 1997; Mumford, Scott, Gaddis \& Strange, 2002). Though, transformational leadership theories have emphasized encouraging creativity as a primary function of leaders (Bass, 1985; Conger, 1999; Tichy \& Ulrich, 1984), on the contrary, there is considerable debate on the leadership innovation literature in terms of the lack of transactional leadership' ability to stimulate employee innovative work behavior (Basu \& Green, 1997). Additionally, a surge of literature has revealed inconsistent results in terms of the role played by the transformational and transactional leadership styles in engendering their followers innovative work behavior (Kahai, Sosik \& Avolio, 2003; Shin \& Zhou, 2003), as some studies reported positive impact of these two leadership styles on employees' innovative work behavior while other studies showed that they have negative effects, so, the lack of empirical evidence that directly addresses the impact of leadership styles on employees' creativity, makes further studies useful. Moreover, given the inconsistent results, it seems important to identify possible causes of these discrepancies (Pieterse, Knippenberg, Schippers \& Stam, 2010).

\section{Literature review and hypotheses development}

\subsection{Leadership styles and innovative work behavior}

There are many factors that enhance the innovative work behavior of employees, but leadership was perceived as the most prominent situational factor that promotes the generation of such behavior among employees (Huang, Wu, Lu \& Lin, 2016), so, leadership has often been suggested as one of the key stimulants that triggers such behavior. This is because a leader can create attitudes and conditions that evoke the innovative work behavior of their sub-ordinates and thus reach desirable creative outcomes (Wu \& Lin, 2018). In this vein, the role of a leader as influencing the innovative work behavior of employees may vary from being a transactional leader to be a transformational leader (Oke, Munshi \& Walumba, 2009). Hence, leaders should strive to create an environment that induces their subordinates innovative work behavior (Sethibe \& Steyn, 2016).

\subsubsection{Transformational leadership style and innovative work behavior}

Transformational leadership creates an appropriate environment for employees who seek to engage in innovative work behaviors, especially since those behaviors are complex and risky due to the uncertainty in the success of the idea (Masood \& Afsar, 2017). Transformational leaders are developing in their sub-ordinates a sense of self-efficacy (Kark et al., 2018). Thus, followers inspired by their transformational leaders recognize precisely what it is anticipated from them to achieve and they are willing to exert any effort to contribute to the attainment of the organization' goals, accordingly they are in ultimate search for innovative solutions of approaching their tasks, which is reflected on their innovative behavior ( $\mathrm{Ng}$, 2017). Inspirational motivation, a component of transformational leadership, is considered a key factor in stimulating employees' innovative work behavior through a positive compelling future vision, while intellectual stimulation creates motivation to challenge existing assumptions and view problems from new perspectives that increase potential opportunities to generate creative solutions to these problems (Bass \& Avolio, 2000). Therefore, this inspirational motivation of those leaders will enable their sub-ordinates to perform their work at an exceptional level that exceeds expectations and promotes the ability of these employees to generate new ideas and to be more innovative (Ismail, Mohamad, Mohamed, Rafiuddin \& Zhen, 2010). Additionally, followers respond to the individualized consideration by reciprocating their leaders concern towards this by positively contributing to their organizations through innovative endeavor (Eisenbeiss, van Knippenberg \& Boerner, 2008). Furthermore, the transformational leaders' idealized influence triggers followers to imitate the formers' behavior in pursuing novel and creative ideas (Çekmecelioğlu \& Özbağ, 2016). Furthermore, this positive relationship between transformational leadership and innovation stemmed from leaders holding the capacity to stimulate their followers' intrinsic motivation to initiate in creative and innovative outcomes (Zhang, Miner, Boutros, Rogulja \& Crickmore, 2018). Therefore, it is hypothesized:

$\mathrm{H}_{1}$ Transformational leadership positively impacts employees' innovative work behavior.

\subsubsection{Transactional leadership style and innovative work behavior}

The negative relationship between the transactional leadership style and employees' innovative work behavior is based on the conception of their style as it is directed towards job performance and not innovation stemmed from the reciprocal relation between the leader and their sub-ordinates in terms of contingent rewards for satisfactory performance or punishments in case their performance was below the preset levels or encompasses deficiencies. According to their style, the leader identifies their desire to accomplish job tasks and how to perform them through permanent notes that by its turn impede employees' innova- 
tive work behavior (Masood \& Afsar, 2017). According to Pieterse et al. (2010), transactional leadership might have a negative impact on employees' innovative work behavior because their leadership style is more oriented towards employees' performance than stimulating novel and original activities. In contrast, one study found that transactional leaders also encourage their employees to possess innovative work behavior at almost the same level practiced by transformational leadership (Contreras, Espinosal, Dornberger \& Acosta, 2017). There is what Khaola and Sephelane (2013) emphasized that transactional leadership is negatively related to employees' innovative work behavior, while Boerner, Eisenbeiss and Griesse (2007) found no relationship between transactional leadership style and employees innovative work behavior. Therefore, it is hypothesized:

$\mathrm{H}_{2}$ Transactional leadership negatively impacts employees' innovative work behavior.

\subsubsection{Laisser-Faire leadership style and innovative work behavior}

It is noteworthy that employee development is not a concern for their leadership style, based on a belief that subordinates can take care of themselves. The focus of their style of leadership is not on performance or employees. The leader relinquishes controlling their employees and avoids being in contact with them (Puni, Agyemang, \& Asamoah, 2016). Their leadership style avoids all forms of interaction with sub-ordinates; thus, it is absent when needed, and represents the approach of giving up responsibilities and avoiding decision-making. Their style of leadership may only intervene to make corrections when something goes wrong, and does not keep tracks of the violations committed by their sub-ordinates, and therefore their leadership style does not support creativity and does not motivate its followers to practice innovative work behavior (Munawar, Muhammad \& Ishfaq, 2011). Therefore, it is hypothesized:

$\mathrm{H}_{3}$ Transactional leadership negatively impacts employees' innovative work behavior.

\section{Methodology}

The current study was conducted in Al-Ahliyya Amman University Employees. The study pursues a descriptive analytical approach using cross-sectional survey that was administered to employees working in their foundation. The questionnaire consisted of three parts; first part that captures data pertinent to the respondents' background; the second part discusses/highlights the three leadership styles namely transformational leadership style, transactional leadership style and Laisser-Faire leadership style, where the Multi Factor Questionnaire (MLQ) with 32 items was adopted to measure these styles. Meanwhile, employees' innovative work behavior items were adopted from previous studies (De Jong \& Den Hartog, 2008; Kheng, June \& Mahmood, 2013; Oukes, 2010). The statistical techniques used in the study include factor analysis, Cronbach Alpha, Pearson correlation and multiple regression (SPSS version 23).

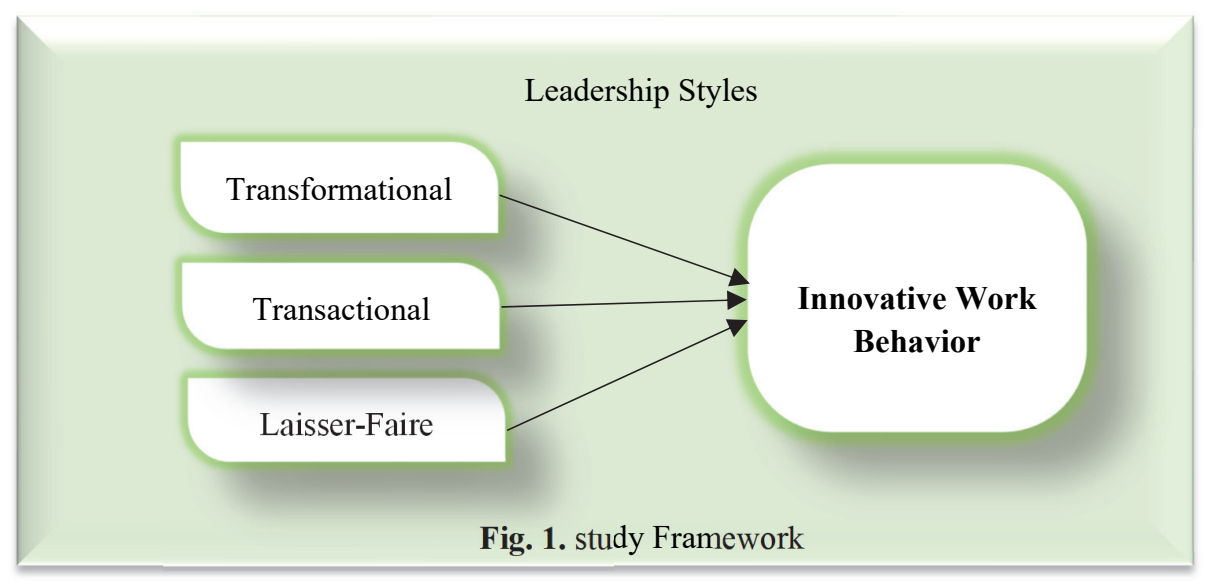

Table 1

Personal characteristics of the participants

\begin{tabular}{ccccc}
\hline \multirow{2}{*}{ Gender } & Male & Female & & \\
& 53.7 & 46.7 & $41-50$ & More than 51 \\
& $25-30$ & $31-40$ & 30.2 & 14.2 \\
\hline \multirow{2}{*}{ Age } & 17.9 & 37.7 & Bachelor & Post Studies \\
& School Diploma & Diploma & 53.3 & 32.8 \\
\hline \multirow{2}{*}{ Education } & 4.4 & 9.5 & $11-15$ & More than 16 \\
& $0-5$ & $6-10$ & 23.0 & 44.0 \\
\hline \multirow{2}{*}{ Experience } & 11.4 & 21.6 & Department Head & Director \\
& Employee & Supervisor & 20.2 & 15.1 \\
\hline \multirow{2}{*}{ Job } & 50.9 & 13.7 & & \\
\end{tabular}




\section{Findings}

A total of 430 responses were elicited from the study sample. Among them, 229 were males, while females were 201 . Above two third of the respondents were within the age between 31 to 50, years. In terms of education level, most of the respondents who have a bachelor's degree or above reached 229 members of the sample. Regarding the years of experience, the majority have 16 years and above. Furthermore, the bulk of respondents were employees. Details of respondents' background are illustrated in table 1 .

Table 2 shows the factor loading for all constructs of scale items. The factor loadings of each item to the whole scale are above the minimum verge/limit of 0.45 which shows that all the adapted items have internal validity. Each item Coefficient Correlation is significance at 0.01 level. Therefore, the construct does not have any kind of validity or reliability issues.

Table 2

The results of factor loading

\begin{tabular}{|c|c|c|c|c|c|c|c|}
\hline Item & Component & Item & Component & Item & Component & Item & Component \\
\hline TF1 & 0.554 & TL1 & 0.417 & LF1 & 0.699 & IWB1 & 0.589 \\
\hline TF2 & 0.740 & TL2 & 0.564 & LF2 & 0.830 & IWB2 & 0.402 \\
\hline TF3 & 0.827 & TL3 & 0.125 & LF3 & 0.842 & IWB3 & 0.761 \\
\hline TF4 & 0.678 & TL4 & 0.665 & LF4 & 0.815 & IWB4 & 0.807 \\
\hline TF5 & 0.802 & TL5 & 0.774 & LF5 & 0.887 & IWB5 & 0.787 \\
\hline TF6 & 0.775 & TL6 & 0.785 & LF6 & 0.900 & IWB6 & 0.830 \\
\hline TF7 & 0.820 & TL7 & 0.792 & LF7 & 0.858 & IWB7 & 0.822 \\
\hline TF8 & 0.752 & TL8 & 0.765 & LF8 & 0.874 & IWB8 & 0.741 \\
\hline TF9 & 0.842 & & & & & IWB9 & 0.859 \\
\hline TF10 & 0.712 & & & & & IWB10 & 0.675 \\
\hline TF11 & 0.809 & & & & & IWB11 & 0.746 \\
\hline TF12 & 0.694 & & & & & IWB12 & 0.809 \\
\hline TF13 & 0.767 & & & & & IWB13 & 0.670 \\
\hline TF14 & 0.827 & & & & & IWB14 & 0.783 \\
\hline TF15 & 0.814 & & & & & IWB15 & 0.716 \\
\hline TF16 & 0.787 & & & & & & \\
\hline
\end{tabular}

Table 3

The results of Cronbach Alpha

\begin{tabular}{llcc}
\hline Var & Variable Description & No. of Items & Cronbach Alpha \\
\hline Ind1 & Transformational Leadership & 16 & 0.957 \\
Ind2 & Transactional Leadership & 0.778 \\
Ind3 & Laisser-Faire Leadership & 0 & 8 \\
Dep2 & Innovative Work Behavior & 0.939 & 15 \\
\hline
\end{tabular}

As stated in Table 3, the results reveal that all model variables are significantly correlated to each other at $\mathrm{p}<0.01$. Additionally, the overall Cronbach Alpha values are way above the minimum threshold/verge of 0.65 which suggests a good internal consistency of each scale (Gliem \& Gliem, 2003).

Table 4

The summary of Pearson Correlation Coefficient between leadership styles and employees' innovative work behavior

\begin{tabular}{|c|c|c|c|c|}
\hline \multirow[b]{2}{*}{ Variables } & \multicolumn{3}{|c|}{ Dimensions of leadership styles } & \multirow[b]{2}{*}{ Total } \\
\hline & $\begin{array}{c}\text { Transformational } \\
\text { leadership }\end{array}$ & Transactional leadership & $\begin{array}{l}\text { Laisser Faire } \\
\text { leadership }\end{array}$ & \\
\hline Employee Innovative Work Behavior & $.154^{* *}$ & -.079 & $.414^{* *}$ & $.236^{* *}$ \\
\hline Rank & 2 & 4 & 3 & 1 \\
\hline Sig. & .001 & .104 & .000 & .000 \\
\hline
\end{tabular}

**. Correlation is significant at the 0.01 level

*. Correlation is significant at the 0.05 level.

As depicted in Table 4, the correlation results show that there is a positive significant relationship between both Transformational Leadership style and Laisser Faire Leadership style and employees' innovative work behavior. However, Transactional leadership style indicates/reveals an insignificant correlation with innovative work behavior. To determine the extent of each leadership style on employees' innovative work behavior, Multiple Regression Analysis was conducted as illustrated in the Table 5.

Table 5

Multiple regressions between leadership styles and employee innovative work behavior

\begin{tabular}{ccccc}
\hline Model & $\mathrm{R}$ & R. Square & Adjusted R Square & Std. Error of the Estimate \\
\hline 1 & $.462^{\text {a }}$ & .214 & .208 & .88281 \\
\hline
\end{tabular}

a. Predictors: (Constant), Laisser Faire Leadership, Transactional Leadership, Transformational Leadership 
Table 6

The results of ANNOVA test

\begin{tabular}{cccccc}
\hline Model & Sum of Squares & df & Mean Square & F & Sig. \\
\hline Regression & 90.266 & 3 & 30.089 & 38.607 & $.000^{\mathrm{b}}$ \\
Residual & 332.007 & 426 & .779 & \\
Total & 422.273 & 429 & & \\
a. Dependent Variable: IWB_M & & & \\
b. Predictors: (Constant), Laisser Faire Leadership, Transactional Leadership, Transformational Leadership &
\end{tabular}

Table 7

Output of Coefficients ${ }^{\mathrm{a}}$ for the Multiple Regressions

\begin{tabular}{|c|c|c|c|c|c|}
\hline \multirow{2}{*}{ Model } & \multicolumn{2}{|c|}{ Unstandardized Coefficients } & \multirow{2}{*}{$\begin{array}{c}\text { Standardized Coefficients } \\
\text { Beta }\end{array}$} & \multirow{2}{*}{$\mathrm{t}$} & \multirow{2}{*}{ Sig. } \\
\hline & $\mathrm{B}$ & Std. Error & & & \\
\hline (Constant) & 3.743 & .312 & & 11.988 & .000 \\
\hline Transformational Leadership & .309 & .065 & .236 & 4.782 & .000 \\
\hline Transactional Leadership & -.139 & .066 & -.096 & -2.091 & .037 \\
\hline Laisser_Faire_Leadership & -.295 & .046 & -.309 & -6.418 & .000 \\
\hline
\end{tabular}

a. Dependent Variable: IWB_M

As stated in Table 7, the results reveal that the transformational leadership has high Beta value of .236 with significant level of 0.000 . Hence, it proves that transformational leadership has a significant positive impact on employees' innovative work behavior. Thus, $\mathrm{H}_{1}$ is statistically supported. However, the results show that both transactional leadership and Laisser-Faire leadership have significant negative impact on employees' innovative work behavior. Therefore, $\mathrm{H}_{2}$ and $\mathrm{H}_{3}$ are statistically supported.

\section{Discussion and Conclusion}

The aim of the study is to investigate the impact of leadership styles on employees' innovative work behavior in Al-Ahliyya Amman University Employees. The findings reveal that leadership styles have a significant impact on employees' innovative work behavior as $\left(\mathrm{R}^{2}=0.214\right)$, illustrating that the three leadership styles interpret the variance in employees' innovative work behavior in their foundation. Their result is in agreement with the findings revealed by previous studies (Cheng, Cao, Zhong, He \& Qian, 2019; Škudienè, Augutytè-Kvedaravičienè, Demeško \& Suchockis, 2018; Wu \& Lin, 2018; Naqvi, Ullah, S. \& Javed, 2017; Hansen \& Pihl-Thingvad, 2017; Arthur, Wagstaff \& Hardy, 2016; Kurt \& Yahyagil, 2015; Herrmann \& Felfe, 2012; Khan, Aslam \& Riaz, 2012).).

However, transformational leadership was the single leadership style that exerts positive significant impact on employees' innovative work behavior in Al-Ahliyya Amman University Employees. Their result confirms similar findings in previous studies (Cheng et al., 2019; Günzel-Jensen, Hansen, Jakobsen \& Wulff, 2018; Sethibe \& Steyn, 2016; Wu \& Lin, 2018; Kang, Solomon \& Choi, 2015; Khan et al., 2012).There is attributed to the recognition depicted by followers of transformational leaders, in addition to being treated respectfully, as well as the assertion of those leaders to the crucial importance of enhancing a collective sense of responsibility have urged those followers to practice innovative work behavior.

Meanwhile, the findings reveal that transactional leadership and Laisser-Faire leadership have significant negative impact on employees' innovative work behavior. Their result agrees with similar findings in previous studies (Škudienè, et al., 2018; Naqvi et al., 2017; Khan et al., 2012). The probable justification is that transactional leadership style is more focused on its followers' performance orientation rather than going beyond their and practicing innovative work behavior. In terms of Laisser-Faire leadership, their style is a passive avoidant by nature that averts getting involved in making decisions or responding to its followers which impede any innovative initiation from the part of their followers.

The study concluded that the leaders of the Al-Ahliyya Amman University Employees who belong to the transformational leadership style are keen to treat their sub-ordinates as important individuals and let them realize their value, but they do not spend time teaching and training their subordinates, while on the other side, leaders who belong to the transactional leadership style express their satisfaction when the performance of their sub-ordinates matches their expectations, However, they do not trace all mistakes committed by their sub-ordinates, but with regard to leaders belonging to the Laisser-Faire style, the results show that they avoid getting involved when problems arise. Despite that, they are convinced that necessary procedures should be taken before problems become chronic. Regarding employees' innovative work behavior, it has been found that employees of Al-Ahliyya Amman University Employees are exerting efforts to develop their work issues, while not seeking to discover and secure the necessary funding to implement new ideas.

\subsection{Theoretical Contribution}

Their study contributes to the leadership and innovation literature by adding more knowledge to the identification of which leadership style exerts positive impact on practicing innovative work behavior that was employed by transformational leadership style. Thus, the study will be responding to a recent call in the leadership and innovation literature that urged to determine the leadership style that promotes followers' innovative work behavior (Kark et al., 2018). Furthermore, the study is 
adding more empirical evidence to the negative impact of both transactional and Laisser-Faire styles on employees' innovative work behavior.

\subsection{Managerial Implications}

The study recommended leaders who belong to the transformational leadership style of different job levels (supervisors, department heads and directors) to incorporate a span of their time for the purpose of educating and training their subordinates. Moreover, the study recommended guiding/steering leaders at Al-Ahliyya Amman University Employees who practice the transactional leadership style to clarify the errors committed by sub-ordinates as they may constitute valuable opportunities for their subordinates to learn and to acquire more skills. Furthermore, the study suggested advising leaders who belong to the Laisser-Faire leadership style to stop practicing their leadership style, as it is characterized by passivity and to shift to practicing transformational leadership style, which has proven to have a significant impact on enhancing employees' innovative work behavior. The study also recommended leaders of different job levels to encourage their sub-ordinates to align creative ideas that they put forward with companies and commercial institutions related to those ideas, where these ideas may constitute a path to develop their operations, products or services, and then support those creative ideas and provide appropriate funding for them.

\section{References}

Anderson, N., Potočnik, K. \& Zhou, J. (2014). Innovation and creativity in organizations: A state-of-the-science Review, prospective commentary, and guiding framework. Journal of Management, 40(5), 1297-1333.

Arthur, C., Wagstaff, C. \& Hardy, L. (2016). Leadership in Sport Organizations. In: Wagstaff, CRD (ed). The Organizational Psychology of Sport: Key issues and practical applicants. Abingdon: Routledge, pp. 153-176.

Bass, B. \& Avolio, B. (2000). MLQ Multifactor Leadership Questionnaire Redwood City: Mind Garden.

Bass, B. (1985). Leadership: Good, better, best. Organizational Dynamics, 13(3), 26-40.

Basu, R. \& Green, S. (1997). Leader-member exchange and transformational leadership: an empirical examination of innovative behaviors in leader-member dyads. Journal of Applied Social Psychology, 27(6), 477-499.

Boerner, S., Eisenbeiss, S. \& Griesser, D. (2007). Follower behavior and organizational performance: The impact of transformational leaders. Journal of Leadership \& Organizational Studies, 13(3), 15-26.

Çekmecelioğlu, H. \& Özbağ, G. (2016). Leadership and Creativity: The Impact of Transformational Leadership on Individual Creativity. Procedia - Social and Behavioral Science, 235, 243 - 249. doi: 10.1016/j.sbspro.2016.11.020.

Cheng, C., Cao, L., Zhong, H., He, Y. \& Qian, J. (2019). The Influence of Leader Encouragement of Creativity on Innovation Speed: Findings from SEM and fsQCA. Sustainability, 11(9), 1-17.

Conger, J. (1999). Charismatic and transformational leadership in organizations: An insider's perspective on these developing streams of research. Leadership Quarterly, 10, 145-169.

Contreras, F., Espinosal, J., Dornberger, U. \& Acosta, Y. (2017). Leadership and employees' innovative work behavior: Test of a mediation and moderation model. Asian Social Science, 13(9), 9-25.

De Jong, J. \& Den Hartog, D. (2010). Measuring innovative work behavior. Creativity and Innovation Management, 19(1), 23-26.

De Jong, J. \& Den Hartog, D. (2008). Innovative work behavior: Measurement and validation. EIM Business and Policy Research, 8(1), 1-27.

De Spiegelaere, S., Van Gyes, G., De Witte, H., Niesen, W. \& Van Hootegem, G. (2014). On the relation of job insecurity, job autonomy, innovative work behavior and the mediating effect of work engagement. Creativity and Innovation Management, 23(3), 318-330.

Dörner, N. (2012). Innovative work behavior: The roles of employee expectations and effects on job performance. Doctoral dissertation, Verlag nicht ermittelbar.

Eisenbeiss, S., van Knippenberg, D. \& Boerner, S. (2008). Transformational leadership and team innovation: Integrating team climate principles. Journal of Applied Psychology, 93(6), 1438-1446.

Gliem, J. \& Gliem, R. (2003). Calculating, interpreting, and reporting Cronbach's alpha reliability coefficient for Likert-type scales. Midwest Research-to-Practice Conference in Adult, Continuing, and Community Education.

González-Romá, V. (2008). La innovación en los equipos de trabajo. Papeles del psicólogo, 29(1), 32-40.

Günzel-Jensen, F., Hansen, J., Jakobsen, M. \& Wulff, J. (2018). A two-pronged approach? Combined leadership styles and innovative behavior. International Journal of Public Administration, 41(12), 957-970.

Hansen, J. \& Pihl-Thingvad, S. (2017). Leadership styles and innovative Work behavior. Paper presented at 21st International Research Society on Public Management Conference, Budapest, Hungary.

Herrmann, D. \& Felfe, J. (2012). Effects of Leadership Style, Creativity Technique and Personal Initiative on Employee Creativity. British Journal of Management, 25(2), 209-227.

Hong, Y., Liao, H., Raub, S. \& Han, J. (2016). What it takes to get proactive: An integrative multilevel model of the antecedents of personal initiative. Journal of Applied Psychology, 101(5), 687-701.

Huang, K., Wu, J., Lu, S. \& Lin, Y. (2016). Innovation and technology creation effects on organizational performance. Journal of Business Research, 69(6), 2187-2192.

Ismail, A., Mohamad, M., Mohamed, H., Rafiuddin, N. \& Zhen, K. (2010). Transformational and Transactional Leadership Styles as a Predictor of Individual Outcomes. Theoretical \& Applied Economics, 17(6), 89-104. 
Joo, B. \& Bennett, R. (2018). The influence of proactivity on creative behavior, organizational commitment, and job performance: evidence from a Korean multinational. Journal of International \& Interdisciplinary Business Research, 5(1), 120.

Kahai, S., Sosik, J. \& Avolio, B. (2003). Effects of leadership style, anonymity, and rewards on creativity-relevant processes and outcomes in an electronic meeting system context. The Leadership Quarterly, 14(4-5), 499-524.

Kang, J., Solomon, G. \& Choi, D. (2015). CEOs' leadership styles and managers' innovative behavior: Investigation of intervening effects in an entrepreneurial context. Journal of Management Studies, 52(4), 531-554.

Kark, R., Van Dijk, D. \& Vashdi, D. (2018). Motivated or demotivated to be creative: The role of self-regulatory focus in transformational and transactional leadership processes. Applied Psychology, 67(1), 186-224.

Khan, M., Aslam, N. \& Riaz, M. (2012). Leadership styles as predictors of innovative work behavior. Pakistan Journal of Social \& Clinical Psychology, 9(2), 17-22.

Khaola, P. \& Sephelane, R. (2013). Leadership, organizational citizenship and innovative work behaviors in Lesotho: Exploratory evidence. Journal of Language, Technology \& Entrepreneurship in Africa, 4(2), 46-58.

Kheng, Y., June, S. \& Mahmood, R. (2013). The determinants of innovative work behavior in the knowledge intensive business services sector in Malaysia. Asian Social Science, 9(15), 47-59.

Kurt, İ. \& Yahyagil, M. Y. (2015). Universal values, creative behavior and leadership: Turkish case. International Business Research, 8(6), 89-103.

Liu, D., Jiang, K., Shalley, C., Keem, S. \& Zhou, J. (2016). Motivational mechanisms of employee creativity: A meta-analytic examination and theoretical extension of the creativity literature. Organizational Behavior and Human Decision Processes, 137, 236-263.

Masood, M. \& Afsar, B. (2017). Transformational leadership and innovative work behavior among nursing staff. Nursing Inquiry, 24(4), 1-14.

Mintzberg, H. (2010). Developing Leaders? Developing Countries? Oxford Leadership Journal, 1 (2).

Mumford, M., Scott, G., Gaddis, B. \& Strange, J. (2002). Leading creative people: Orchestrating expertise and relationships. The Leadership Quarterly, 13(6), 705-750.

Munawar, K., Muhammad, R. \& Ishfaq, A. (2011), Transformational, transactional, and Laissez-Faire styles of teaching faculty as a predictor of satisfaction, and extra effort among the students: evidence from higher education institutes. Interdisciplinary Journal of Research in Business, 1(4), 130-135.

Mytelka, L. \& Smith, K. (2002). Policy learning and innovation theory: an interactive and co-evolving process. Research Policy, 31(8), 1467-1479.

Naqvi, J., Ullah, S. \& Javed, B. (2017). Effect of leadership styles on employees' innovative behavior: The mediating role of employees' creativity. European Journal of Business and Management, 9(28), 27-37.

$\mathrm{Ng}$, T. (2017). Transformational leadership and performance outcomes: analyses of multiple mediation pathways. The Leadership Quarterly. 28(3), 385-417

Oke, A., Munshi, N. \& Walumbwa, F. (2009). The influence of leadership on innovation processes and activities. Organizational Dynamics, 38(1), 64-72.

Oukes, T. (2010). Innovative work behavior: a case study at a tire manufacturer (Bachelor's thesis, University of Twente).

Pieterse, A., Van Knippenberg, D., Schippers, M. \& Stam, D. (2010). Transformational and transactional leadership and innovative behavior: The moderating role of psychological empowerment. Journal of Organizational Behavior, 31(4), 609-623.

Puni, A., Agyemang, C. \& Asamoah, E. (2016). Leadership styles, employee turnover intentions and counterproductive work behaviors. International Journal of Innovative Research and Development, 5(1), 1-7.

Saleem, M., Tufail, M., Atta, A. \& Asghar, S. (2015). Innovative workplace behavior, motivation level, and perceived stress among healthcare employees. Pakistan Journal of Commerce and Social Sciences (PJCSS), 9(2), 438-446.

Sarros, J., Cooper, B. \& Santora, J. (2008). Building a climate for innovation through transformational leadership and organizational culture. Journal of Leadership \& Organizational Studies 15(2), 145-158.

Sethibe, T. \& Steyn, R. (2016). Organizational climate, innovation and performance: A systematic review. Journal of Entrepreneurship and Innovation in Emerging Economies, 2(2), 161-174.

Shin, S. \& Zhou, J. (2003). Transformational leadership, conservation, and creativity: evidence from Korea. Academy of Management Journal, 46(6), 703-714.

Shojaei, M. \& Siuki, M. (2014). A study of relationship between emotional intelligence and innovative work behavior of managers. Management Science Letters, 4(7), 1449-1454.

Škudienè, V., Augutytè-Kvedaravičienè, I., Demeško, N. \& Suchockis, A. (2018). Exploring the relationship between innovative work behavior and leadership: moderating effect of locus of control. Organizations and Markets in Emerging Economies, 9(1), 21-40.

Tichy, N. \& Ulrich, D. (1984). SMR forum: The leadership challenge--A call for the transformational leader. Sloan Management Review (pre-1986), 26(1), 59.

Wang, C., Tsai, H. \& Tsai, M. (2014). Linking transformational leadership and employee creativity in the hospitality industry: The influences of creative role identity, creative self-efficacy, and job complexity. Tourism Management, 40, 79-89.

Wu, J. \& Lin, Y. (2018). Interaction between the different leadership styles on innovative behavior based on organizational culture in ecological industry: Empirical research from China, Ekoloji, 27(106), 643-649. 
Zhang, S., Miner, L., Boutros, C., Rogulja, D. \& Crickmore, M. (2018). Motivation, perception, and chance converge to Make a binary decision, Neuron, 99(2), 376-388.

Zhou, J., \& Hoever, I. J. (2014). Research on workplace creativity: A review and redirection. Annual Review of Organizational Psychology and Organizational Behavior, 1(1), 333-359.

Zhou, J. \& Shalley, C. (2011). Deepening our understanding of creativity in the workplace: A review of different approaches to creativity research.

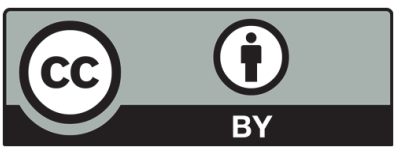

(C) 2020 by the authors; licensee Growing Science, Canada. This is an open access article distributed under the terms and conditions of the Creative Commons Attribution (CC-BY) license (http://creativecommons.org/licenses/by/4.0/). 